\title{
Influence of early weaning beef cows on the performance of male progeny and the need for winter protein supplementation*
}

\author{
Donald Llewellyn 1,2\#, Emily Schlickau², Twig Marston ${ }^{3}$, Karl Harborth ${ }^{4}$, Ryan Breiner², \\ John Unruh², Michael Dikeman ${ }^{2}$ \\ ${ }^{1}$ Washington State University Extension, Benton County, Kennewick, USA; \\ ${ }^{\#}$ Corresponding Author: don.1lewellyn@,wsu.edu \\ ${ }^{2}$ Department of Animal Sciences and Industry, Kansas State University, Manhattan, USA \\ ${ }^{3}$ Northeast Research and Extension Center, University of Nebraska-Lincoln, Norfolk, USA \\ ${ }^{4}$ AgCenter, Louisiana State University, Baton Rouge, USA \\ Received 15 October 2013; revised 16 November 2013; accepted 29 November 2013 \\ Copyright (C) 2013 Donald Llewellyn et al. This is an open access article distributed under the Creative Commons Attribution License, \\ which permits unrestricted use, distribution, and reproduction in any medium, provided the original work is properly cited.
}

\section{ABSTRACT}

One hundred and three Hereford $\times$ Angus crossbred, spring-calving cows were used to determine the influence of early weaning performance of their male progeny and the need for cowherd winter supplementation. Treatments were early weaned (EW; 115-d of age) and normal weaned calves (NW; 220-d of age). Both intact and castrated male progeny were randomly allotted to early and normal weaning calf management treatments. Following summer grazing and weaning protocols, cows within each weaning group were randomly assigned to receive winter supplementation treatments of LOW $(1.26 \mathrm{~kg} / \mathrm{hd} / \mathrm{d})$ or HIGH $(1.81 \mathrm{~kg} / \mathrm{hd} / \mathrm{d})$ amounts of a protein supplement containing $450 \mathrm{~g} / \mathrm{kg}$ CP (DM basis). Cows whose calves were weaned early gained more BW and BCS $(P<0.0001)$ during the summer grazing season than cows with normally weaned calves. Early weaned calves had higher ADG between weaning dates; WDA and BW by age 242 d $(P<0.05)$ than normally weaned calves. Normal weaned steer calves ended the experiment with the lightest BW $(P<0.05)$ when compared to early weaned steer calves, early weaned bull calves, and normal weaned bull calves. At calving time the EWLOW supplement fed cows had greater $(P=0.04)$ BCS but similar $(P=0.74)$ BW when compared with cows with normally weaned calves that received $100 \%$ of

${ }^{*}$ Contribution No. 13-286-J from the Kansas Agricultural Experiment Station. their supplement (NWHIGH). Early weaning has the potential to reduce the amount of supplement required during the winter grazing period.

Keywords: Early Weaning; Beef Cows; Bulls; Steers; Protein Supplementation

\section{INTRODUCTION}

Early weaning decreases nutrient requirements of beef cows, allowing for an increase in cow body condition score and carrying capacity of pastures [1-5]. This approach is valuable to spring-calving herds in areas with decreasing forage quality during mid-summer. Early weaning may also be an option during drought conditions and the associated reductions in forage supply, which can force cow-calf producers to consider management strategies to maintain stocking rates and cow and calf performance [6]. Early weaning can also increase conception rates and shorten the interval from parturition to conception in first calf heifers $[7,8]$.

Early weaning of beef calves at 90 to $120-\mathrm{d}$ of age provides an opportunity to increase nutrient intake by feeding concentrates at a time when their growth potential is high. Early weaning has been shown to increase feed efficiency and marbling scores compared with normal weaning protocols $[3,4,9,10]$. In the United States, most male calves used for meat production are castrated. Steers have improved quality grades, more intramuscular fat, and improved tenderness of longissimus steaks than bulls, whereas bulls grow more rapidly, utilize feed more efficiently, and produce carcasses with greater cutability compared with steers $[11,12]$. Although using bulls for 
this type of meat production was researched extensively in the early 1980s, it has not been thoroughly addressed in combination with the practice of early weaning.

In early weaning programs, summer and fall increases in cow body weight (BW) and body condition score (BCS) may have the potential to moderate the herd's dependence on winter protein supplementation while grazing low-quality forage; consequently, significant reductions in winter feed costs might be realized.

The objectives of this study were to investigate the use of early weaning and castration on calf growth. In addition, the effect of early weaning on summer cow BW and BCS as well as the need for winter protein supplementation was evaluated.

\section{MATERIALS AND METHODS}

The care and handling of animals during this experiment was conducted in accordance with the guidelines of the Institutional Animal Care and Use Committee at Kansas State University.

\subsection{Cow-Calf Performance Study}

One-hundred-three multiparous, crossbred cows nursing spring-born male beef calves (mean birth date = March 2) were used in this experiment to measure cow and calf performance related to calf weaning age. Calves had commercial Hereford $\times$ Angus cross dams and were sired by purebred Hereford and Angus bulls. Calves were blocked by birth date and sire, and then randomly assigned to one of four treatment groups: 1) early weaned steers, 2) early weaned bulls, 3) normally weaned steers, and 4) normally weaned bulls. Cow-calf pairs from all treatments were commingled within four native-grass pastures near Manhattan, KS, USA (average stocking rate $=3.6$ ha/cow-calf pair). All pastures had ad libitum access to a commercial salt/mineral mixture and water. Cows were examined for pregnancy by rectal palpation following traditional weaning time in the fall.

Lactation period for the early weaned and normally weaned treatments were 115-d and 220-d, respectively. On both weaning dates, BW and BCS ( 1 = emaciated and 9 = obese) as described by [13] were determined by averaging four independent BCS estimates made by trained technicians. In addition, on the normal weaning date, external backfat of cows was determined by ultrasound (Aloka 500, Aloka, Wallingford, CT; transducer $=3.5$ MHZ linear array with a $12.5-\mathrm{cm}$ window, model UST 5021-125; and Cattle Performance Enhancement Company cattle software, Oakley, KS, USA).

Herd health maintenance programs and breeding seasons (May 21 through July 21) were similar between pastures and treatments. Briefly, all calves were injected with Fortress 7 (Pfizer Animal Health, Cambridge, MA,
USA) at $86 \mathrm{~d}$ of age and calves assigned to the steer treatments were castrated and implanted with Component E-C (VetLife, West Des Moines, IA, USA).

At 115-d of age, the calves assigned to early weaning were weaned, injected with Bovi-Shield 4 (Pfizer), and assigned to pens according to their sex class. This resulted in four pens of calves (two bull pens and two steer pens); all were fed a complete starter ration (Wildcat Feeds LLC, Topeka, KS, USA; Table 1). Daily feed intake was recorded for the pens, and calves were treated for illness as necessary. Feed intake averaged $5.13 \mathrm{~kg} / \mathrm{d}$ as fed. At $134 \mathrm{~d}$ of age, weight was recorded and early weaned calves were shipped to the Western Kansas Agricultural Research Center in Hays, Kansas, USA. The growing ration for early weaned calves is presented in Table 2. At 183-d of age, the early weaned calves were adjusted to a finishing ration.

Table 1. Starter rations fed to either early or normal weaned calves from weaning until feedlot facility arrival.

\begin{tabular}{ccc}
\hline & \multicolumn{2}{c}{ Ration (\%) $^{2}$} \\
\hline Ingredients $^{1}$ & Starter ration $^{2}$ & Starter ration $^{3}$ \\
\hline Brome hay & - & 51.3 \\
Wheat midds & 30.0 & 16.7 \\
Soy hulls & 30.0 & - \\
Hominy & - & 20.2 \\
Distillers grain solubles & 14.9 & - \\
Shelled corn & 10.0 & - \\
Cottonseed hulls & 8.0 & - \\
Vitamin premix & 4.1 & 2.4 \\
Cane molasses & 2.0 & - \\
Limestone salt & 1.1 & 0.6 \\
\hline
\end{tabular}

${ }^{1}$ All amounts reported as a percentage of diet, as fed; ${ }^{2}$ Fed to early weaned calves from 115 to $134-\mathrm{d}$ of age, ${ }^{3}$ Fed to normally weaned calves from 221 to 241-d of age.

Table 2. Feedlot rations fed to both early and normal weaned calves after arriving at the feedlot facilities.

\begin{tabular}{|c|c|c|}
\hline & \multicolumn{2}{|c|}{ Ration \% } \\
\hline Ingredients $^{1}$ & Growing $^{2}$ & Finishing $^{3}$ \\
\hline Sorghum silage & 43.9 & 32.3 \\
\hline Grain sorghum, finely ground & 43.2 & 58.8 \\
\hline Soybean meal & 8.9 & 6.1 \\
\hline Rumensin/Tylan ${ }^{\circledR}$ premix $^{4}$ & 1.0 & 0.7 \\
\hline Ammonium sulfate & 0.4 & 0.3 \\
\hline Limestone & 2.1 & 1.5 \\
\hline Urea & - & - \\
\hline Salt & 0.5 & 0.4 \\
\hline
\end{tabular}

${ }^{1}$ All amounts reported as a percentage of dry matter in diet; ${ }^{2} \mathrm{Fed}$ to early weaned calves only from 134 to $182 \mathrm{~d}$ of age; ${ }^{3} \mathrm{Fed}$ to early weaned calves only from 183 to $241 \mathrm{~d}$ of age; ${ }^{4}\left(\right.$ Tylan $^{\circledR}$; ELANCO ANIMAL HEALTH, Greenfield, IN, USA). 
The calves designated for normal weaning remained with the cows on native bluestem range near Manhattan, Kansas, USA with no creep feed throughout the summer. At 201-d of age, they were injected with Bovi-Shield 4 (Pfizer), One Shot (Pfizer), and Fortress 7 (Pfizer). Calves were weaned and weighed at 220-d of age and randomly assigned to pens according to their sex class. This resulted in four pens (i.e. two bull pens and two steer pens), which were fed an average of $1.8 \mathrm{~kg} / \mathrm{d}$ of a grower ration (Wildcat Feeds LLC, Topeka, KS, USA; Table 1) and $4.7 \mathrm{~kg} / \mathrm{d}$ of prairie hay. At 242-d of age, calves were weighed and shipped to the Western Kansas Agricultural Research Center, Hays, KS. Early weaned calves were also weighed at 242-d of age.

\subsection{Beef Cow Supplementation Study}

Ninety-six pregnant, multiparous Hereford $\times$ Angus beef cows grazing low-quality tallgrass prairie during the winter were used to evaluate the influence of early weaning of calves on their need for protein supplementation during the subsequent winter feeding period. At the initiation of the study (November 14), BW and BCS were determined as described by [14] using the same ninepoint scale utilized during the breeding season. Body condition scores were determined to the nearest 0.25 BCS by a panel of four trained technicians and averaged to provide the $\mathrm{BCS}$ score at each weighing. Initial $\mathrm{BW}$ and BCS averaged $578 \pm 61.5 \mathrm{~kg}$ and $5.5 \pm 0.6$, respectively, and additional BW and BCS were collected approximately every $60-\mathrm{d}$ and within $48 \mathrm{~h}$ after calving.

Cows were blocked by pasture (three pastures; each pasture = approximately 136 ha), stratified by BW and $\mathrm{BCS}$, and randomly assigned to one of three grazing groups within weaning treatment (i.e., early weaning or normal weaning). As described by [15], the wintergrazed, dormant forage was a mixture of $\mathrm{C}_{3}$ and $\mathrm{C}_{4}$ species in the Kansas Flint Hills region; forage quality of the pastures was described by [14]. Two winter supplementation levels were randomly assigned to the feeding groups. The four treatments utilizing a common soybean meal-grain sorghum supplement $(\mathrm{CP}=450 \mathrm{~g} / \mathrm{kg}$; DM basis) were as follows: 1) early weaning, HIGH (EWHIGH; $1.81 \mathrm{~kg}$ /day of the supplement); 2) early weaning, LOW (EWLOW; $1.26 \mathrm{~kg}$ /day of the supplement); 3) normal fall weaning, HIGH (NWHIGH; 1.81 $\mathrm{kg} / \mathrm{d}$ of the supplement); and 4) normal fall weaning, LOW (NWLOW; $1.26 \mathrm{~kg} / \mathrm{d}$ of the supplement). The HIGH groups were provided supplement to meet the nutrient requirements for pregnant beef cows of similar type and physiological status [16]. Supplementation commenced on November 14 and continued until calving, at which time all cows were handled similarly and provided with $5.44 \mathrm{~kg} / \mathrm{d}$ of alfalfa hay until new-growth forage was available. During the supplementation period, all cows were gathered at 06:30 to 09:00 $\mathrm{h}$ from their respective pastures and bunk-fed. Supplementation occurred three days per week (i.e. Monday, Wednesday, and Friday), with the amount of supplement prorated to deliver the designated daily quantity. Cows had ad libitum access to a commercial mineral mix and water throughout the experiment.

\subsection{Statistical Analysis}

Individual live animal measurements were analyzed using a $2 \times 2$ factorial treatment structure consisting of weaning time and sex class using the PROC MIXED procedure of SAS (2000; SAS Institute Inc., Cary, NC, USA). Animals were blocked by birth date and sire for treatment assignment. Fixed effects were weaning time and sex class, whereas block and block interaction were considered random effects. Pen measurements of DMI and G:F were analyzed using a $2 \times 2$ factorial treatment structure consisting of weaning time and sex class using the PROC MIXED procedure of SAS (2000). Pen was used as the experimental unit. Fixed effects included weaning time and sex class, whereas block and block interactions were considered random effects. All interaction and main effect means for all analyses were separated using the LSD procedure when the respective $f$-test was significant $(P<0.05)$.

Cow supplementation data were analyzed by ANOVA utilizing the GLM procedure of SAS (2000) as a randomized complete-block design. Treatment, block, and treatment nested within block were included in the model. Grazing groups were considered the experimental units, and two grazing groups of each treatment were included in each of the three pastures (block) representing six replications per treatment. Treatment within block was specified as the random term for testing treatment effects. Treatment means were determined by the LSMEANS option of SAS (2000), and predetermined orthogonal contrasts were used for treatment comparisons. The proportion of cows pregnant at the end of the breeding season was analyzed by the FREQ procedure of SAS.

\section{RESULTS AND DISCUSSION}

\subsection{Cow-Calf Performance Study}

Summer performance of cows is reported in Table 3. When calves reached an average of 115-d of age, there were no differences in BW or BCS of the cows; however, cows that had their calves weaned early were heavier $(P$ $<0.0001$ ) at the normal fall weaning time (i.e., normal calves weaned on October 6). Cows that had their calves weaned early gained $52.6 \mathrm{~kg}$ more BW $(P<0.0001)$ during the summer grazing season than cows with calves weaned at the normal time. Consistent with summer BW data, cows with early weaned calves had greater BCS ( $P$ 
Table 3. Effect of weaning treatment on cow body weight (BW), body condition score (BCS), and external backfat of spring-calving cow-calf pairs during the summer grazing season.

\begin{tabular}{|c|c|c|c|c|}
\hline \multirow{2}{*}{ Item } & \multicolumn{2}{|c|}{ Weaning treatment } & \multirow{2}{*}{ SEM } & \multirow{2}{*}{ P-value } \\
\hline & Early $^{1}$ & Normal $^{2}$ & & \\
\hline Number of cows & 52 & 51 & & \\
\hline Average calving date & March 2 & March 2 & & \\
\hline \multicolumn{5}{|l|}{$\mathrm{BW}, \mathrm{kg}$} \\
\hline June 25 (calves 115 -d of age) & 535.7 & 533.4 & 8.5 & \\
\hline October 6 (calves 220-d of age) & 599.7 & 544.8 & 3.8 & 0.0001 \\
\hline BW change, June 25 to Oct. $6, \mathrm{~kg}$ & 64.0 & 11.4 & 3.8 & 0.0001 \\
\hline \multicolumn{5}{|l|}{$\mathrm{BCS}^{3}$} \\
\hline June 25 (calves 115 -d of age) & 5.0 & 4.9 & 0.08 & \\
\hline October 6 (calves 220-d of age) & 6.2 & 4.9 & 0.07 & 0.0001 \\
\hline BCS change, June 25 to Oct. 6 & 1.2 & 0.0 & 0.07 & 0.0001 \\
\hline Backfat on Oct. $6, \mathrm{~mm}$ & 7.6 & 4.3 & 0.02 & \\
\hline Cows pregnant on Oct. $6, \%$ & 96 & 100 & & 0.49 \\
\hline
\end{tabular}

${ }^{1}$ Early treatment group weaned on June $25 ;{ }^{2}$ Normal treatment group weaned on October $6 ;{ }^{3}$ Body condition score: $1=$ emaciated; $9=$ obese [13].

$<0.0001)$ at normal weaning time in the fall. Cows with fall-weaned calves only maintained BCS during the summer, whereas cows with early weaned calves gained 1.2 BCS more $(P<0.0001)$ than normal weaned cows from early weaning time until normal fall weaning time. This result is in agreement with the findings of $[4,5]$. Previous investigations have noted the relationship between body condition and reproductive performance $[17,18]$. In addition, ultrasound backfat measurements showed that early weaned cows had $3.3 \mathrm{~mm}$ more backfat at the normal fall weaning time. Pregnancy data noted no differences between the early and normal weaned treatments for the proportion of cows pregnant at the normal fall weaning time.

Early weaned calves had similar $(P>0.10)$ live weights initially, at 115 -d of age, but were heavier $(P<$ 0.05 ) at 242-d of age than normally weaned cattle (Table 4).

Early weaned calves had weights per d of age (WDA) initially (115-d of age) similar to normally weaned cattle (Table 4). Early weaned calves had greater $(P<0.05)$ WDA and had greater $(P<0.05)$ BW at 242-d (Table 4) than normally weaned calves. In agreement, [19] reported that normally weaned steers had lower ADG and took longer to reach harvest. In another study, [20] reported that early weaned steers had higher ADG from 203 to 230 -d of age. In our study, a weaning time $\times$ sex class interaction $(P<0.05)$ for weight was observed at $242-d$ in which normally weaned steers $(321.4 \mathrm{~kg}$, SEM $=6.1)$ were lighter $(P<0.05)$ than normally weaned bulls $(339.7 \mathrm{~kg}, \mathrm{SEM}=6.5)$, early weaned bulls $(354.8$ $\mathrm{kg}, \mathrm{SEM}=6.7)$, and early weaned steers $(358.2 \mathrm{~kg}$, SEM
$=6.9)$. Early weaned calves had greater $(P<0.01) \mathrm{ADG}$ from 115 to 242 -d of age $(1.21 \mathrm{~kg} / \mathrm{d}$ vs $1.07 \mathrm{~kg} / \mathrm{d})$ than normally weaned calves (Table 4), likely because they were fed a higher plane of nutrition. Other investigators $[1,4,9,10,21,22]$, found that early weaned calves gained faster from early weaning to the normal weaning date, and that these calves were heavier at approximately 205-d of age than calves weaned at the normal time. During the same time period, bull calves had greater $(P<$ $0.05)$ ADG than steer calves. It is well documented that bulls gain faster than steers due to the anabolic effects of testosterone $[11,12]$, but in this study it appears the androgenic effect of implants in the steer calves moderated those effects.

A study by [9] showed that normally weaned calves experienced compensatory growth and superior ADG compared with early weaned calves during the first $28 \mathrm{~d}$ in the feedlot. The normally weaned cattle in our study might have experienced less growth as they were adjusting to both a new diet and environment. In general, early weaned calves grew faster from early weaning until the normally weaned calves had adjusted to the feedlot. Bulls and steers had similar weights and WDA at all times (Table 4). In contrast, [11] reported that bulls were heavier than steers at various ages.

Comparison of the efficiency of early and normally weaned cattle may depend on the composition of gain, the degree of nutritional restriction prior to weaning, and likely compensatory growth of the normally weaned cattle. Bull calves consumed less $(P<0.05)$ feed DM but gained with similar feed efficiency as the steers from 134 to 242-d of age (Table 5). 
Table 4. Effects of weaning treatment and castration on calf growth characteristics.

\begin{tabular}{ccccc}
\hline \multirow{2}{*}{ Item } & \multicolumn{2}{c}{ Weaning time } & \multicolumn{2}{c}{ Castration group } \\
\cline { 2 - 5 } & Early $^{1}$ & Normal $^{2}$ & Steers & Bulls \\
\hline $\begin{array}{c}\text { No. of } \\
\text { observations } \\
\text { Weight, kg }\end{array}$ & 45 & 51 & 47 & 49 \\
$115 \mathrm{~d}$ & $161.5(3.2)$ & $167.1(3.0)$ & $165.7(3.1)$ & $163.0(3.0)$ \\
$242 \mathrm{~d}$ & $322.8^{\mathrm{a}}(5.2)$ & $300.9^{\mathrm{b}}(4.9)$ & $309.0(4.7)$ & $314.6(4.5)$ \\
WDA, kg/d & & & & \\
$115 \mathrm{~d}$ & $1.41(0.03)$ & $1.46(0.03)$ & $1.46(0.03)$ & $1.41(0.03)$ \\
$242 \mathrm{~d}$ & $1.35^{\mathrm{a}}(0.02)$ & $1.25^{\mathrm{b}}(0.02)$ & $1.29(0.02)$ & $1.31(0.02)$ \\
ADG, kg/d & & & & \\
$115-242 \mathrm{~d}$ & $1.21^{\mathrm{a}}(0.06)$ & $1.07^{\mathrm{b}}(0.06)$ & $1.10^{\mathrm{c}}(0.05)$ & $1.19^{\mathrm{d}}(0.05)$ \\
\hline
\end{tabular}

${ }^{1}$ Early weaned calves were weaned at $115-\mathrm{d}$ of age and entered the feedlot at 134-d of age; ${ }^{2}$ Normally weaned calves were weaned at 220-d of age and entered the feedlot at 242-d of age; ${ }^{\text {ab }}$ Within a row and weaning time, means with different superscript letters differ $(P<0.05)$; ${ }^{\text {cd }}$ Within a row and sex class, means with different superscript letters differ $(P<0.05)$.

Table 5. Effects of castration on dry matter intake and gain to feed ratio (G:F) of early weaned male calves.

\begin{tabular}{cccc}
\hline \multirow{2}{*}{ Item } & \multicolumn{2}{c}{ Castration group } & \multirow{2}{*}{ SEM } \\
\cline { 2 - 3 } & Steers & Bulls & \\
\hline 134 to 242 d of age & & & \\
Number of observations & 2 & 2 & \\
Dry matter intake, $\mathrm{kg} / \mathrm{d}$ & $7.50^{\mathrm{a}}$ & $7.39^{\mathrm{b}}$ & 0.015 \\
G:F & 0.145 & 0.185 & 0.012 \\
\hline
\end{tabular}

$\overline{{ }^{\mathrm{ab}} \text { Within a row and sex class, means that do not have a common superscript }}$ letter differ $(P<0.05)$.

\subsection{Beef Cow Supplementation Study}

The provision of ruminally degradable protein (RDP) to beef cattle grazing low-quality forage has been shown to improve forage utilization $[23,24]$. Other investigations reported increases in $\mathrm{BW}$ and $\mathrm{BCS}$ as a result of provision of supplemental protein [14,25]. Cow BW and BCS data are presented in Tables 6 and 7. Winter BW and BCS changes are similar to those observed in previous protein supplementation studies with spring-calving cows [14,26,27]. Cows with calves weaned early were heavier (EW vs NW; $P<0.01$ ) at the start of the winter grazing season. Cumulative BW losses from the start of the winter grazing season until calving tended $(P=0.07)$ to be greater for cows that had their calves weaned early. However, final BW at calving was greater $(P=0.01)$ for cows that had their calves weaned early (i.e., 115-d of age). This result indicates that when cows have spring calves weaned at the traditional time in the fall, feeding to meet NRC requirements results in performance comparable to cows with calves weaned early.
Comparing the HIGH vs LOW supplementation levels, cows receiving the $\mathrm{HIGH}$ treatments gained more $(P=$ $0.02) \mathrm{BW}$ during the fall/early winter period (November 14 to January 7$)$ and tended to lose less $(P=0.07) \mathrm{BW}$ than the LOW treatments from November 14 to spring calving.

NWHIGH cows that had their calves weaned at 220-d were compared with cows with calves weaned at $115-d$ on the EWLOW regimen to determine if the increase in weight achieved by early weaning could allow for a reduction in the amount of feed required to sustain the cows in adequate $\mathrm{BW}$ and BCS during the winter and until parturition the following spring. During the first period of the winter grazing season, NWHIGH had greater $(P=0.02) \mathrm{BW}$ gains than the cows with early weaned calves on the reduced supplementation regimen (EWLOW). Likewise, cumulative BW losses from the start of the winter grazing season to calving were $20 \mathrm{~kg}$ greater $(P=0.02)$ for the EWLOW cows than those in the NWHIGH treatment. Final BW at calving reflected no differences $(P=0.74)$ between NWHIGH and EWLOW, which indicates that the cows with early weaned calves that started the winter grazing season with greater $(P<0.01)$ BW were able to use that weight to their advantage and therefore maintain acceptable $\mathrm{BW}$ at calving. In addition, it has been suggested that delivering feed resources based on their availability and allowing cows to cycle in their weights allows for an increased efficiency of nutrient utilization [28]. However, care should be taken to prevent severe nutrient restriction that could negatively affect fetal development [29].

Consistent with BW observations, winter BCS changes (Table 7) were similar to those observed in previous protein supplementation studies with spring-calving cows [14,26,28]. Cows with early weaned calves started the winter grazing season approximately 0.9 BCS greater $(P<0.01)$ than the cows with calves weaned at 220-d. Cows that had their calves weaned at 115-d lost $(P<0.01)$ more BCS when compared with cows that had their calves removed at 220-d during the entire winter grazing/supplementation season until calving. Cows on the HIGH vs LOW regimens tended $(P<0.07)$ to differ in BCS change only during the January 7 to January 13 period. Although no significant differences in BW were observed between NWHIGH and EWLOW at calving, BCS were greater $(P=0.04)$ for EWLOW than for NWHIGH. This finding suggests that although the EWLOW cattle were allowed to lose more BCS during the winter grazing period, the additional BCS gained during the summer following early weaning more than compensated for the losses. All cows were combined after calving and handled as one management group until the subsequent weaning date that was approximately one year after the NW date. The NWLOW cows had the lowest 
Table 6. Amounts and changes in body weight (BW) of early weaned (EW) and normal weaned (NW) beef cows fed different amounts (LOW and HIGH) of protein supplement during winter grazing of dormant tall grass pastures.

\begin{tabular}{|c|c|c|c|c|c|c|c|c|}
\hline \multirow{2}{*}{ Item } & \multicolumn{4}{|c|}{ Treatment $^{1}$} & \multirow{2}{*}{$\mathrm{SEM}^{2}$} & \multicolumn{3}{|c|}{ Statistical comparisons ( $P$-values) } \\
\hline & EWHIGH & EWLOW & NWHIGH & NWLOW & & EW vs. NW & HIGH vs. LOW & NWHIGH vs. EWLOW \\
\hline No. of cows & 23 & 24 & 24 & 26 & & & & \\
\hline Initial weight, $\mathrm{kg}$ (Nov. 14) & 616 & 581 & 561 & 555 & 9.9 & $<0.01$ & 0.08 & 0.19 \\
\hline \multicolumn{9}{|c|}{ Period weight changes, kg } \\
\hline Nov. 14-Jan. 7 & 14 & 8 & 17 & 10 & 1.95 & 0.25 & 0.02 & 0.02 \\
\hline Jan. 7-Feb. 13 & 14 & 16 & 21 & 20 & 3.22 & 0.23 & 0.94 & 0.36 \\
\hline Feb. 13-calving ${ }^{3}$ & -72 & -78 & -70 & -77 & 3.94 & 0.72 & 0.15 & 0.2 \\
\hline \multicolumn{9}{|c|}{ Cumulative weight change, $\mathrm{kg}$} \\
\hline Nov. 14-calving ${ }^{3}$ & -45 & -53 & -33 & -46 & 4.89 & 0.07 & 0.07 & 0.02 \\
\hline Final weight, kg & 570 & 523 & 528 & 505 & 9.16 & 0.01 & 0.01 & 0.74 \\
\hline Calf birth BW, kg & 41 & 38.5 & 42.3 & 42.4 & 1.29 & 0.08 & 0.36 & 0.07 \\
\hline
\end{tabular}

${ }^{1}$ Treatment: EW = June 23-115 d of lactation; NW = Oct. $15-220 \mathrm{~d}$ of lactation; $\mathrm{HIGH}=1.81 \mathrm{~kg} \cdot \mathrm{hd}^{-1} \cdot \mathrm{d}^{-1}$ of soybean meal-milo supplement $(450 \mathrm{~g} / \mathrm{kg}$ crude protein; $\mathrm{DM}$ basis); $\mathrm{LOW}=1.26 \mathrm{~kg} \cdot \mathrm{hd}^{-1} \cdot \mathrm{d}^{-1}$ of soybean meal-milo supplement. ${ }^{2} \mathrm{SEM}=$ standard error of the mean. ${ }^{3}$ Average calving date $=\mathrm{March} 15$.

Table 7. Amounts and changes in body condition scores (BCS) of early weaned (EW) and normal weaned ( NW) beef cows fed different amounts (LOW and HIGH) of protein supplement during winter grazing of dormant tall grass pastures.

\begin{tabular}{|c|c|c|c|c|c|c|c|c|}
\hline \multirow{2}{*}{ Item } & \multicolumn{4}{|c|}{ Treatment $^{2}$} & \multirow{2}{*}{$\mathrm{SEM}^{3}$} & \multicolumn{3}{|c|}{ Statistical comparisons ( $P$-values) } \\
\hline & EWHIGH & EWLOW & NWHIGH & NWLOW & & EW vs. NW & HIGH vs. LOW & NWHIGH vs. EWLOW \\
\hline No. of cows & 23 & 24 & 24 & 26 & & & & \\
\hline Initial BCS-Nov. 14 & 5.8 & 6 & 5.1 & 5.1 & 0.148 & $<0.01$ & 0.81 & $<0.01$ \\
\hline \multicolumn{9}{|c|}{ BCS changes } \\
\hline Nov. 14-Jan. 7 & -0.13 & -0.19 & -0.09 & -0.16 & 0.052 & 0.55 & 0.21 & 0.2 \\
\hline Jan. 7-Feb. 13 & -0.04 & -0.12 & 0.02 & -0.09 & 0.045 & 0.3 & 0.07 & 0.05 \\
\hline Feb. 13-calving ${ }^{4}$ & -0.44 & -0.3 & -0.11 & -0.07 & 0.076 & $<0.01$ & 0.26 & 0.13 \\
\hline \multicolumn{9}{|c|}{ Cumulative BCS change } \\
\hline Nov. 14-calving ${ }^{4}$ & -0.61 & -0.62 & -0.19 & -0.31 & 0.085 & $<0.01$ & 0.44 & 0.01 \\
\hline Final BCS at calving & 5.25 & 5.35 & 4.91 & 4.74 & 0.127 & $<0.01$ & 0.77 & 0.04 \\
\hline Cows pregnant ${ }^{5}, \%$ & 95.5 & 88.9 & 95.5 & 73.9 & & & & \\
\hline
\end{tabular}

${ }^{1}$ Body condition score: 1 = emaciated; $9=$ obese. ${ }^{2}$ Treatment: EW $=$ June 23 ; NW $=$ Oct. 15 ; HIGH $=1.81 \mathrm{~kg} \cdot \mathrm{hd}^{-1} \cdot \mathrm{d}^{-1}$ of soybean meal-milo supplement $(450$ $\mathrm{g} / \mathrm{kg} \mathrm{CP}$; DM basis); LOW $=1.26 \mathrm{~kg} \cdot \mathrm{hd}^{-1} \cdot \mathrm{d}^{-1}$ of soybean meal-milo supplement. ${ }^{3} \mathrm{SEM}=$ standard error of the mean. ${ }^{4}$ Average calving date $=\mathrm{March} 15$. ${ }^{5} \mathrm{Cows}$ pregnant following winter supplementation, Chi square, $P=0.07$.

rebreeding rate $(P=0.07)$ of all treatment groups.

\section{CONCLUSIONS}

In conclusion, early weaning is a viable option to increase BW and BCS of beef cows during the summer. This could be a useful tool in drought or other pasturelimiting situations. Increasing BW and BCS before entering the rigors of winter grazing can also be beneficial.

Early weaning and winter supplementation taken together demonstrates the potential of allowing producers to feed less supplement and, therefore, could represent a cost saving in cow-calf feeding systems; however, feeding less than $70 \%$ of the normal supplementation regimen may result in significant $\mathrm{BW}$ and $\mathrm{BCS}$ losses and reductions in reproductive performance.

\section{REFERENCES}

[1] Peterson, G.A., Turner, T.B., Irvin, K.M., Davis, M.E., Newland, H.W. and Harvey, W.R. (1987) Cow and calf performance and economic considerations of early weaning of fall-born beef calves. Journal of Animal Science, 64, 15-22. 
[2] Short, R.E., Grings, E.E., MacNeil, M.D., Heitschmidt, R.K., Haferkamp, M.R. and Adams, D.C. (1996) Effects of time of weaning, supplement, and sire breed of calf during the fall grazing period on cow and calf performance. Journal of Animal Science, 74, 1701-1710.

[3] Myers, S.E., Faulkner, D.B., Ireland, F.A., Berger, L.L. and Parrett, D.F. (1999) Production systems comparing early weaning to normal weaning with or without creep feeding for beef steers. Journal of Animal Science, 77, 300-310.

[4] Myers, S.E., Faulkner, D.B., Ireland, F.A. and Parrett, D.F. (1999) Comparison of three weaning ages on cow-calf performance and steer carcass traits. Journal of Animal Science, 77, 323-329.

[5] Story, C.E., Rasby, R.J., Clark, R.T. and Milton, C.T. (2000) Age of calf at weaning of spring-calving beef cows and the effect on cow and calf performance and production economics. Journal of Animal Science, 78, 1403-1413.

[6] Mulliniks, J.T., Waterman, R.C. and Geary, T.W. (2013) Economics of early weaning in northern great plains beef cattle production system. Agricultural Sciences, 4, 219233. http://dx.doi.org/10.4236/as.2013.45031

[7] Laster, D.B., Glimp, H.A. and Gregory, K.E. (1973) Effects of early weaning on postpartum reproduction of cows. Journal of Animal Science, 36, 734-740.

[8] Lusby, K.S., Wettemann, R.P. and Turman, E.J. (1981) Effects of early weaning calves from first-calf heifers on calf and heifer performance. Journal of Animal Science, 53, 1193-1197.

[9] Fluharty, F.L., Loerch, S.C., Turner, T.B., Moeller, S.J. and Lowe, G.D. (2000) Effects of weaning age and diet on growth and carcass characteristics in steers. Journal of Animal Science, 78, 1759-1767.

[10] Schoonmaker, J.P., Fluharty, F.L., Loerch, S.C., Turner, T.B., Moeller, S.J. and Wulf, D.M. (2001) Effect of weaning status and implant regimen on growth, performance, and carcass characteristics of steers. Journal of Animal Science, 79, 1074-1084.

[11] Field, R.A. (1971) Effect of castration on meat quality and quantity. Journal of Animal Science, 32, 849-858.

[12] Seideman, S.C., Cross, H.R., Oltjen, R.R. and Schanbacher, B.D. (1982) Utilization of the intact male for red meat production: A review. Journal of Animal Science, 55, 826-840.

[13] Lemenager, R.P., Funston, R.N. and Moss, G.E. (1991) Manipulating nutrition to enhance (optimize) reproduction. Proceedings of 2nd Grazing Livestock Nutrition Conference, Steamboat Springs, 2-3 August 1991, 13-31.

[14] Llewellyn, D.A., Cochran, R.C., Marston, T.T., Grieger, D.M., Farmer, C.G. and Wickersham, T.A. (2006) Influence of limited fall protein supplementation on performance and forage utilization by beef cattle grazing lowquality native grass pastures. Animal Feed Science and Technology, 127, 234-250. http://dx.doi.org/10.1016/j.anifeedsci.2005.09.006

[15] Owensby, C.E., Coyne, P.I., Ham, J.M., Auen, L.M. and Knapp, A.K. (1993) Biomass production in a tallgrass prairie ecosystem exposed to ambient and elevated $\mathrm{CO}_{2}$. Ecological Applications, 3, 644-653. http://dx.doi.org/10.2307/1942097

[16] NRC (2000) Nutrient requirements to beef cattle. 7th Revised Edition, National Academy Press, Washington DC.

[17] Morrison, D.G., Spitzer, J.C. and Perkins, J.L. (1999) Influence of prepartum body condition score change on reproduction in multiparous beef cows calving in moderate body condition. Journal of Animal Science, 77, 10481054.

[18] Lents, C.A., White, F.J., Ciccioli, N.H., Wettemann, R.P., Spicer, L.J. and Lalman, D.L. (2008) Effects of body condition score at parturition and postpartum protein supplementation on estrous behavior and size of the dominant follicle in beef cows. Journal of Animal Science, 86, 2549-2556. http://dx.doi.org/10.2527/jas.2008-1114

[19] Shike, D.W., Faulkner, D.B., Cecava, M.J., Parrett, D.F. and Ireland, F.A. (2007) Effects of weaning age, creep feeding, and type of creep on steer performance, carcass traits, and economics. The Professional Animal Scientist, 23, 325-332.

[20] Myer, D.L., Kerley, M.S., Walker, E.L., Keisler, D.H., Pierce, V.L., Schmidt, T.B., Stahl, C.A., Linville, M.L. and Berg, E.P. (2005) Growth rate, body composition, and meat tenderness in early vs. traditionally weaned beef calves. Journal of Animal Science, 83, 2752-2761.

[21] Neville, W.E. and McCormick, W.C. (1981) Performance of early- and normal-weaned beef calves and their dams. Journal of Animal Science, 52, 715-724.

[22] Lusby, K.S., Gill, D.R., Anderson, D.M., Gardner, T.L. and Dolezal, H.G. (1990) Limit feeding vs. full feeding high concentrate diets to early weaned calves-Effects on performance to slaughter. Oklahoma Agricultural Experiment Station Research Report, MP-129, Stillwater.

[23] Köster, H.H., Cochran, R.C., Titgemeyer, E.C., Vanzant, E.S., Abdelgadir, I. and St. Jean, G. (1996) Effect of increasing degradable intake protein on intake and digestion of low-quality, tallgrass-prairie forage by beef cows. Journal of Animal Science, 74, 2473-2481.

[24] Bodine, T.N., Purvis II, H.T., Ackerman, C.J. and Goad, C.L. (2000) Effects of supplementing hay with corn and soybean meal on intake, digestion, and ruminal measurements by beef steers. Journal of Animal Science, 78, 3144-3154.

[25] Bohnert, D.W., Schauer, C.S. and DelCurto, T. (2002) Influence of rumen protein degradability and supplementation frequency on performance and nitrogen use in ruminants consuming low-quality forage: Cow performance and efficiency of nitrogen use in wethers. Journal of Animal Science, 80, 1629-1637.

[26] Farmer, C.G., Cochran, R.C., Simms, D.D., Klevesahl, E.A., Wickersham, T.A. and Johnson, D.E. (2001) The effects of several supplementation frequencies on forage use and the performance of beef cattle consuming dormant tallgrass prairie forage. Journal of Animal Science, 79, 2276-2285.

[27] Stalker, L.A., Adams, D.C., Klopfenstein, T.J., Feuz, D.M. and Funston, R.N. (2006) Effects of pre- and postpartum 
nutrition on reproduction in spring calving cows and calf feedlot performance. Journal of Animal Science, 84, 2582-2589. http://dx.doi.org/10.2527/jas.2005-640

[28] Freetly, H.C. and Nienaber, J.A. (1998) Efficiency of energy and nitrogen loss and gain in mature cows. Journal of Animal Science, 76, 896-905.
[29] Freetly, H.C., Nienaber, J.A. and Brown-Brandl, T. (2008) Partitioning of energy in pregnant beef cows during nutritionally induced body weight fluctuation. Journal of Animal Science, 86, 370-377.

http://dx.doi.org/10.2527/jas.2007-0250 